\title{
METODE INOKULASI BUATAN UNTUK MENGUJI INFEKSI Peronosclerospora maydis PENYEBAB PENYAKIT BULAI TANAMAN JAGUNG
}

\section{Artificial Inoculation Methods to Test The Infection of Peronosclerospora Maydis The Causal Agent of Maize Downy Mildew}

\author{
Satriyo Restu Adhi ${ }^{1}$, Fitri Widiantini ${ }^{2}$, Endah Yulia ${ }^{2}$ \\ ${ }^{1}$ Program Studi Magister Agronomi Konsentrasi Proteksi Tanaman, Fakultas Pertanian, \\ Universitas Padjadjaran \\ ${ }^{2}$ Departemen Hama dan Penyakit Tumbuhan, Fakultas Pertanian, Universitas Padjadjaran, \\ Jatinangor, Jl. Raya Bandung Sumedang KM 21, Jatinangor 45363 \\ Korespondensi : fitri.widiantini@unpad.ac.id
}

Diterima 30 Desember 2018 / Disetujui 28 Mei 2019

\begin{abstract}
ABSTRAK
Keberadaan penyakit bulai akibat Peronosclerospora maydis pada tanaman jagung mampu menyebabkan kehilangan hasil hingga $100 \%$. Pengendalian penyakit bulai dengan menggunakan varietas tahan dinilai cukup efektif. Di dalam pengembangan varietas tahan, seleksi ketahanan calon varietas baru harus dilakukan dan hal ini akan melibatkan inokulasi buatan. Tujuan dari penelitian ini adalah untuk mendapatkan metode inokulasi buatan Peronosclerospora maydis yang efektif pada tanaman jagung pada skala rumah kaca. Penelitian dilaksanakan di Laboratorium Bioteknologi Proteksi Tanaman dan rumah kaca Departemen Hama dan Penyakit Tumbuhan, Fakultas Pertanian, Universitas Padjadjaran pada bulan Oktober hingga Desember 2018. Bahan tanaman yang diinokulasikan berupa kecambah dan bibit tanaman jagung. Metode inokulasi buatan yang diujikan terdiri atas: (1) Sisip daun terinfeksi bulai pada kecambah (SD), (2) Semprot suspensi konidia pada kecambah (SI), (3) Sisip daun bergejala bulai + semprot suspensi konidia pada kecambah (SS), (4) Rendam kecambah pada suspensi konidia (RS), (5) Semprot suspensi konidia pada bibit (SB), dan dua perlakuan tanpa inokulasi (kontrol). Dari hasil percobaan metode sisip daun (SD) menyebabkan $83.3 \%$ tanaman jagung terinfeksi bulai dan dinilai sebagai metode inokulasi buatan yang efisien.
\end{abstract}

Kata kunci: bulai, jagung, inokulasi buatan, Peronosclerospora maydis.

\begin{abstract}
Downy mildew disease caused by Peronosclerospora maydis in maize plants can cause yield loss up to $100 \%$. Disease management of downy mildew by using resistant varieties is considered quite effective. One of the steps to develop resistant varieties is resistance testing of the new variety candidates that involve artificial inoculation. The purpose of this study was to obtain an effective artificial inoculation method of Peronosclerospora maydis in maize
\end{abstract}

Cite this as: Adhi, S, R.Widhiantini, F. dan Yulia, E. (2019). Metode inokulasi buatan untuk menguji infeksi Peronosclerospora maydis penyebab penyakit bulai tanaman jagung. Jurnal Agro, 6(1), 77-86 https://doi.org/10.15575/4409 
plants in a greenhouse. The research was conducted at the Laboratory of Biotechnology of Plant Protection and Glasshouse Department of Plant Pests and Diseases, Agriculture Faculty, Universitas Padjadjaran from October to December 2018. The plant materials used for inoculation were sprout and seedling of maize plant. The artificial inoculation methods tested were (1) infected leaf insertion among the sprouts (SD), (2) conidia suspension spraying on the sprouts (SI), (3) infected leaf insertion + conidia suspension spraying on the sprouts (SS), (4) sprout soaking in conidia suspension (RS), (5) conidia suspension spraying on the seedling (SB), and two treatments without inoculation (controls). The result showed that the insertion of infected leaves among the sprouts (SD) treatment resulted to $83.3 \%$ of infected maize plants by the downy mildew and was considered as the most efficient inoculation method.

Keywords: artificial inoculation, maize, downy mildew, Peronosclerospora maydis.

\section{PENDAHULUAN}

Jagung adalah salah satu sumber pangan penting setelah gandum dan padi. Ketiga sumber pangan tersebut mampu memenuhi lebih dari setengah kebutuhan kalori manusia (Perera \& Weerasinghe, 2014). Bahkan menurut FAO (2016), kebutuhan jagung dunia akan terus meningkat hingga mencapai 3.3 miliar ton pada tahun 2050. Produksi dan kualitas hasil tanaman jagung salah satunya dipengaruhi oleh infeksi patogen tanaman.

Beberapa patogen dilaporkan mampu menginfeksi tanaman jagung. Penyakit bulai yang disebabkan oleh Peronosclerospora spp. merupakan penyakit penting pada tanaman jagung. Penyakit bulai dilaporkan mampu menyebabkan kehilangan hasil hingga $100 \%$ pada pertanaman jagung di Indonesia (Surtikanti, 2013; Talanca, 2013). Penyakit bulai jagung di Indonesia dapat disebabkan oleh tiga spesies yaitu $P$. maydis, $P$. philippinensis, dan $P$. sorghi (Rustiani dkk., 2015b; Muis et al., 2016).

Peronosclerospora spp. merupakan parasit obligat yang hanya hidup, berkembang dan bertahan pada tanaman hidup, dalam hal ini adalah tanaman jagung (Radwan et al., 2011; Korlina \&
Amir, 2015). Sumber inokulum Peronosclerospora spp. dapat berupa inokulum seksual (oospora) maupun inokulum aseksual (konidia).

Gejala penyakit bulai yang ditimbulkan adalah berupa klorotik pada daun yang berkembang secara khas dengan kondisi sejajar dengan tulang daun. Gejala lanjut berupa daun tanaman jagung menjadi kerdil, tegak, dan tampak kering. Selain itu, tanda berupa propagul massa konidia yang mirip seperti tepung pada permukaan atas atau bawah daun dapat ditemukan terutama pada pagi hari (Rustiani, 2015; Rustiani dkk., 2015b).

Keberadaan penyakit bulai yang sangat memengaruhi produksi pada pertanaman jagung tentunya memerlukan pengembangan teknik pengendalian secara berkelanjutan. Pengendalian menggunakan varietas jagung yang tahan terhadap penyakit bulai dinilai sebagai langkah pengendalian yang efektif karena mampu menekan jumlah inokulum awal dan perkembangan penyakit (Pakki, 2017). Tahapan awal untuk mengembangkan varietas tahan terhadap penyakit dapat dilakukan dengan cara menyeleksi aksesi atau calon varietas baru di rumah kaca atau di lapangan dengan melakukan teknik inokulasi penyakit buatan (Giri et al., 2013). 
Keberhasilan inokulasi penyakit buatan akan berperan dalam seleksi karakter ketahanan tanaman melalui ekspresi ataupun tingkat kejadian penyakit pada genotip tanaman yang diuji ketahanannya. Dengan demikian, metode inokulasi penyakit buatan yang efektif akan menentukan efisiensi berkembangnya penyakit pada tanaman yang diinokulasi.

Metode evaluasi status varietas tahan tanaman sorghum menggunakan metode inokulasi buatan terhadap penyakit bulai (P. sorghi) telah dilaporkan oleh Narayana et al. (1995). Metode yang dilakukan adalah dengan menginokulasikan konidia pada kecambah dan bibit tanaman sorghum. Inokulasi konidia dilakukan melalui tiga cara yaitu (1) menyimpan kecambah di antara daun sorghum bergejala bulai sistemik (sandwich), (2) merendam kecambah dalam suspensi inokulum, dan (3) menyemprot kecambah dengan suspensi inokulum. Inokulasi pada bibit dilakukan dengan cara (1) meneteskan suspensi inokulum pada bibit, (2) menyemprotkan suspensi inokulum pada bibit, dan (3) menaburkan propagul inokulum pada bibit. Berdasarkan hasil yang didapatkan bahwa semua metode mampu membuat lebih dari $80 \%$ tanaman sorghum terinfeksi.

Keberhasilan metode inokulasi buatan yang dikembangkan Narayana et al. (1995) diperkirakan dapat diadopsi untuk metode inokulasi buatan spesies Peronosclerospora lain pada tanaman inang lain. Namun demikian, perbedaan tanaman inang dan spesies patogen mungkin akan memberikan keberhasilan inokulasi buatan yang berbeda. Bock et al. (2000) melaporkan bahwa uji patogenesitas $P$. sorghi asal enam lokasi dari wilayah Afrika pada 14 varietas jagung menunjukkan respons nilai kejadian penyakit yang berbeda. Keberhasilan proses inokulasi patogen buatan dan munculnya penyakit sangat bergantung pada interaksi faktor inang, virulensi patogen, dan lingkungan (Agrios, 2005). Oleh karena itu, tujuan penelitian ini adalah untuk mendapatkan metode inokulasi buatan isolat $P$. maydis pada tanaman jagung yang dinilai efisien. Hasil penelitian yang diperoleh akan berkontribusi dalam upaya pengembangan manajemen penyakit bulai pada seleksi ketahanan varietas jagung terhadap $P$. maydis yang berkaitan dengan metode inokulasi buatan yang efisien.

\section{BAHAN DAN METODE}

\section{Waktu dan lokasi penelitian}

Penelitian dilaksanakan di Laboratorium Bioteknologi Proteksi Tanaman dan rumah kaca Departemen Hama dan Penyakit Tumbuhan, Fakultas Pertanian, Universitas Padjadjaran. Percobaan dilakukan pada bulan Oktober hingga Desember 2018.

\section{Sumber inokulum}

Sumber inokulum diambil dari pertanaman jagung terinfeksi bulai di lapangan. Lokasi pengambilan sampel dilakukan di Kecamatan Jatinangor Kabupaten Sumedang dengan koordinat $6^{\circ} .92427778$ LS dan $107^{\circ} .759056$ BT. Pengambilan daun tanaman terinfeksi sebagai sumber inokulum di lapangan menggunakan metode purposive sampling. Daun jagung yang dipilih adalah antara daun pucuk hingga daun ke lima yang menunjukkan gejala sistemik dan terdapat propagul masa konidia di bawah atau di atas permukaan daun. 


\section{Karakterisasi isolat}

Karakteristik morfologi isolat

Peronosclerospora dilakukan berdasarkan pengamatan morfologi dan morfometri. Konidia dan konidiofor $P$. maydis untuk keperluan karakterisasi morfologi ini diperoleh dengan cara melakukan induksi sporulasi buatan dengan metode yang dimodifikasi dari Burhanuddin (2011). Sporulasi buatan ini harus dilakukan untuk mendapatkan morfologi konidiofor dan konidia Peronosclerospora yang utuh dan mempermudah dalam pengamatan.

Daun jagung dari lapangan dicuci dengan air mengalir untuk menghilangkan kotoran dan material lain seperti konidiofor yang rusak dan kemudian dikeringanginkan. Daun yang telah kering angin selanjutnya direndam ke dalam larutan gula $2 \%$, dengan posisi pangkal daun berada di dasar dan terendam $3 \mathrm{~cm}$ pada larutan gula. Selanjutnya daun disungkup menggunakan plastik bening PP (poly propelene) untuk menjaga kelembapan. Daun yang direndam tersebut diletakkan pada area terbuka dan gelap selama satu malam. Pada pagi hari berikutnya konidia dan konidiofor dipanen dari daun yang dikeluarkan dari dalam plastik sungkup.

Daun yang menghasilkan konidia dan konidiofor dicirikan dengan adanya propagul mirip tepung berwarna putih. Propagul tersebut diambil menggunakan plastik berperekat (selotip) bening kemudian ditempelkan pada gelas objek yang sudah diberi satu tetes pewarna methylene blue $2 \%$. Selanjutnya semua sisi pinggiran selotip diberi kuteks bening agar preparat dapat disimpan lebih lama (Hikmawati dkk., 2011; Rustiani et al., 2015a; Widiantini et al.,, 2015).

\section{Metode inokulasi buatan}

Percobaan inokulasi buatan dilakukan menggunakan dua jenis bahan tanam yaitu kecambah dan bibit tanaman jagung. Kedua bahan tanam tersebut berasal dari benih jagung tanpa perlakuan fungisida dan tidak memiliki sifat ketahanan terhadap penyakit bulai. Dalam penelitian ini digunakan benih jagung varietas Bisma karena tidak memiliki sifat ketahanan terhadap penyakit bulai (Aqil dkk., 2012). Agar dapat digunakan sebagai tanaman inang, mula-mula benih jagung dikecambahkan terlebih dahulu pada kotak plastik yang sudah dialasi dengan kapas basah. Selanjutnya benih dibiarkan berkecambah dengan kurun waktu 3-5 hari sampai plumula dan radikula muncul. Bahan tanam bibit dipersiapkan dengan menanam benih jagung secara langsung pada plastik polybag.

Rancangan percobaan yang digunakan adalah Rancangan Acak Kelompok (RAK) terdiri dari 2 perlakuan tanpa inokulasi (kontrol kecambah dan kontrol bibit) dan 5 perlakuan inokulasi buatan (Tabel 1). Masing-masing perlakuan diulang 4 kali dengan 8 tanaman setiap ulangan sehingga total tanaman setiap perlakuan adalah 32 tanaman.

Empat metode inokulasi dilakukan pada kecambah tanaman jagung (Tabel 1). Metode pertama adalah sisip daun terinfeksi (SD) dilakukan dengan menyisipkan kecambah jagung di antara potongan daun jagung bergejala sistemik pada cawan petri yang sudah dialasi kertas tissue lembap. Metode semprot suspensi konidia (SI) dilakukan dengan menyemprotkan suspensi konidia kerapatan $10^{5}$ konidia/ml pada kecambah jagung yang ditempatkan pada cawan petri yang diberi alas kertas tissue lembap. 
Metode rendam suspensi konidia (RS) dilakukan dengan merendam kecambah jagung pada $10 \mathrm{ml}$ suspensi konidia kerapatan $10^{5}$ konidia/ml. Semua perlakuan kecambah diinkubasi pada suhu ruang $\left(22-25^{\circ} \mathrm{C}\right)$ dan kelembapan $80-$ 90\% dengan kondisi gelap selama 48 - 96 jam. Setelah periode inkubasi, kecambah ditanam pada plastik polybag berisi tanah dan ditempatkan di rumah kaca.

Tabel 1. Rancangan perlakuan metode inokulasi buatan

\begin{tabular}{llr}
\hline Bahan tanam & \multicolumn{1}{c}{ Metode } \\
\hline Kecambah & Sisip daun terinfeksi \\
& (SD) & \\
\cline { 2 - 2 } & Semprot & suspensi \\
& konidia pada kecambah \\
& (SI) & \\
\cline { 2 - 2 } & Sisip daun terinfeksi + \\
& Semprot suspensi \\
& konidia pada kecambah \\
& (SS) \\
\cline { 2 - 2 } & Rendam kecambah pada \\
& suspensi konidia (RS) \\
\cline { 2 - 2 } & Kontrol Kecambah (KK) \\
\hline Bibit & Semprot $\quad$ suspensi \\
& konidia pada bibit (SB) \\
\cline { 2 - 2 } & Kontrol bibit (KB) \\
\hline
\end{tabular}

Metode inokulasi buatan pada bibit jagung (Tabel 1) dilakukan dengan cara menyemprotkan suspensi konidia (SB) dengan kerapatan $10^{5}$ konidia/ml menggunakan hand sprayer pada bibit tanaman jagung yang berumur 7 hari, metode ini dilakukan pada pagi hari pukul 06.00 - 07.00. Setelah disemprot tanaman disungkup menggunakan plastik bening untuk menjaga kelembapan.

\section{Pengamatan dan analisis data}

Pengamatan morfologi dan morfometri dilakukan pada 30 buah konidia dan konidiofor. Parameter pengamatan morfologi dan morfometri dilihat berdasarkan bentuk konidia, dimensi konidia dan konidiofor, jumlah percabangan, serta ketebalan dinding sel (Widiantini dkk., 2017). Pengukuran dimensi konidia dan konidiofor dilakukan di bawah mikroskop dengan perbesaran 400x, dibantu kamera mikroskop dan perangkat lunak Scopelmage 9.0.

Pengamatan kejadian penyakit dilakukan setiap 2 hari sekali sampai 21 hari setelah inokulasi (HSI) dan selanjutnya persentase tanaman jagung yang menunjukkan gejala penyakit bulai dapat dihitung (Narayana et al., 1995). Pengamatan dilakukan pada setiap daun dengan melihat ada atau tidaknya gejala klorotik (Gambar 2B) atau tanda berupa propagul masa konidia yang seperti tepung pada permukaan daun. Jumlah tanaman jagung yang terinfeksi dimasukkan ke dalam rumus kejadian penyakit (disease incidence). Selain itu, suhu dan kelembapan relatif di rumah kaca diamati menggunakan alat termohygrometer sebagai data pendukung.

Kejadian penyakit $=\sum \frac{\text { Tanaman terinfeksi }}{\text { Tanaman diamati }} \times 100 \%$

Nilai persentase kejadian penyakit selanjutnya dianalisis menggunakan analisis sidik ragam (Anova) yang diolah menggunakan program SPSS 21. Kemudian jika hasil uji $F$ yang diperoleh menunjukkan adanya perbedaan nyata maka dilakukan uji lanjut dengan uji Duncan taraf nyata $5 \%$.

\section{HASIL DAN PEMBAHASAN}

\section{Karakteristik isolat}

Pengamatan karakteristik morfologi 
dan morfometri konidia dan konidiofor isolat hasil induksi sporulasi ditunjukkan pada Tabel 2. Konidia memiliki bentuk yang bulat (spherical) hingga agak bulat (subspherical) (Gambar 1A), memiliki dinding sel yang tipis $(<1 \mu \mathrm{m})$, dimensi konidia $10.116 \times 7.730-21.636 \times 14.312$ $\mu \mathrm{m}(\mathrm{P} \times \mathrm{L})$. Konidiofor hialin (Gambar $1 \mathrm{C})$, memiliki cabang 2 kali dan percabangan 2 - 4 kali, rata-rata panjang $177.828 \mu \mathrm{m}$. Karakteristik morfologi dan morfometri konidia dan konidiofor Peronosclerospora akan dipengaruhi oleh tanaman inang atau jenis varietas dan kondisi lingkungan (Yao et al., 1991; Telle et al., 2011; Runge et al., 2012).

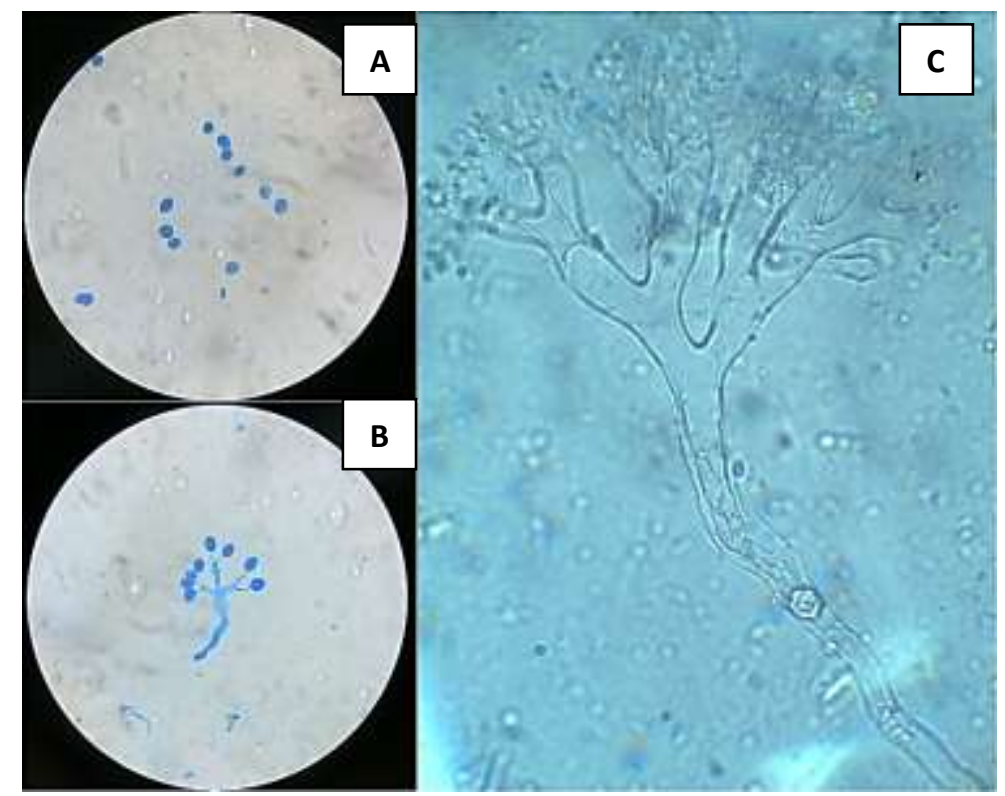

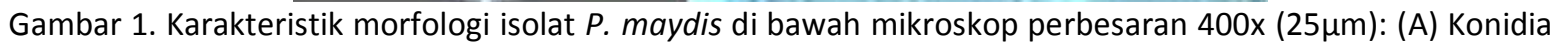
dengan bentuk spherical dan subspherical, (B) Konidiofor dan konidia utuh, (C) Konidiofor yang hialin.

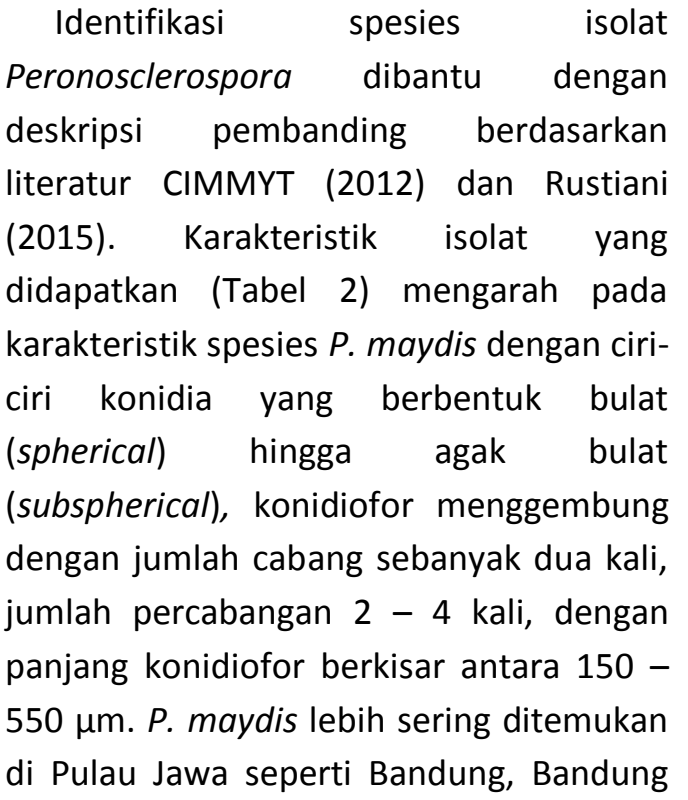

Barat, Boyolali, Garut, Kediri, Klaten, Majalengka, Purwodadi, dan Sumedang (Muis et al., 2016; Widiantini et al., 2017).

\section{Metode inokulasi}

Kejadian penyakit bulai (Gambar 2) berdasarkan lima metode inokulasi buatan berkisar antara 0 hingga 83.3\% (Tabel 3). Persentase kejadian penyakit maksimum terjadi pada perlakuan sisip daun (SD) dengan nilai $83.3 \%$, semprot suspensi (SI) dan kombinasi sisip daun + semprot suspensi (SS) dengan nilai masing-masing $50.0 \%$, semprot bibit (SB) $12.50 \%$, dan rendam suspensi (RS) $0 \%$. 
Tabel 2. Karakteristik morfologi dan morfometri isolat $P$. maydis

\begin{tabular}{ll}
\hline Parameter pengamatan & Hasil \\
\hline Konidia & \\
Bentuk konidia & Spherical - subspherical \\
Dinding sel & Tipis $(<1 \mu \mathrm{m})$ \\
Rataan panjang konidia & $16.220 \mu \mathrm{m}$ \\
Rataan lebar konidia & $11.036 \mu \mathrm{m}$ \\
Rentang dimensi $P$ X & $10.116 \times 7.730-21.636 \times 14.312 \mu \mathrm{m}$ \\
\hline Konidiofor & \\
Cabang & 2 kali \\
Percabangan & $2-4$ kali \\
Rentang dimensi panjang & $103.905-266.144 \mu \mathrm{m}$ \\
Rataan panjang & $177.828 \mu \mathrm{m}$ \\
\hline Spesies & P. maydis \\
\hline
\end{tabular}

Penggunaan kecambah jagung sebagai bahan tanaman inang pada 3 dari 4 metode inokulasi buatan mampu menyebabkan 50.0 - 83.3\% tanaman terinfeksi penyakit bulai. Dalam percobaan ini, metode rendam suspensi (RS) tidak menyebabkan tanaman jagung terinfeksi. Pada uji bahan tanam kecambah, perlakuan sisip daun (SD) menyebabkan kejadian penyakit tertinggi (83.3\%), sedangkan kejadian penyakit terendah (50.0\%) terjadi pada perlakuan semprot suspensi (SI). Ketika perlakuan SD dan SI dikombinasikan (SS), hasilnya menunjukkan bahwa kejadian penyakit mengalami penurunan (62.5\%). Dengan demikian, perlakuan SI pada perlakuan kombinasi ini diperkirakan telah menurunkan tingkat efisiensi infeksi patogen pada perlakuan SD ketika dilakukan secara tunggal. Keberadaan air pada perlakuan SI diduga memengaruhi kondisi sumber inokulum (konidia) secara kuantitas maupun kualitas sehingga berdampak pada proses terjadinya infeksi. Namun demikian, secara statistik perlakuan kombinasi SD + SI (SS) ini tidak berbeda nyata dengan perlakuan SD, tetapi tidak berbeda nyata juga dengan perlakuan SI.

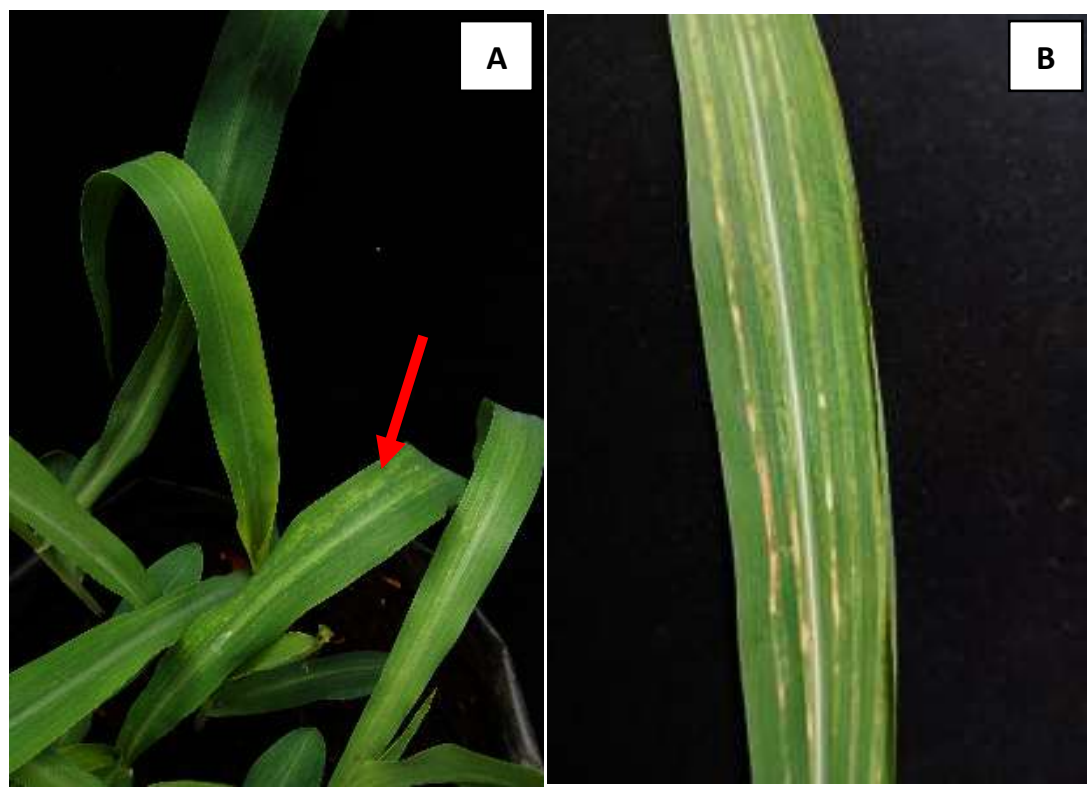

Gambar 2. Kejadian penyakit bulai jagung: (A) Gejala pada daun tanaman muda, (B) Infeksi sistemik dengan gejala khas klorotik memanjang sejajar tulang daun. 
perlakuan Rendam suspensi (RS) disebabkan karena sifat konidia $P$. maydis yang membutuhkan kondisi ketidaktersediaan air untuk menginfeksi kecambah jagung. Hal ini sesuai dengan pernyataan Bonde (1982) bahwa inkubasi konidia selama 10 jam pada air di dalam cawan petri membuat konidia kehilangan viabilitasnya, tetapi konidia yang ditempatkan bersama dengan daun jagung muda akan mempertahankan viabilitasnya meskipun di simpan selama 20 jam. Dengan demikian, disimpulkan bahwa konidia membutuhkan kondisi tidak jenuh air dan terdapat sel tanaman inang muda pada kecambah jagung untuk mendukung proses infeksi.

Tabel 3. Persentase kejadian penyakit bulai pada beberapa metode inokulasi buatan

\begin{tabular}{clc}
\hline \multicolumn{1}{c}{ Bahan Tanam } & \multicolumn{1}{c}{ Metode } & Kejadian Penyakit (\%) \\
\hline Kecambah & Sisip daun (SD) & $83,3 \mathrm{~d}$ \\
& Semprot suspensi (SI) & $50,0 \mathrm{c}$ \\
& Sisip daun + Semprot suspensi (SS) & $62,5 \mathrm{~cd}$ \\
& Rendam suspensi (RS) & $0,0 \mathrm{a}$ \\
\multirow{4}{*}{ Bibit } & Kontrol Kecambah (KK) & $0,0 \mathrm{a}$ \\
& Semprot bibit (SB) & $12,5 \mathrm{~b}$ \\
& Kontrol bibit (KB) & $0,0 \mathrm{a}$ \\
\hline
\end{tabular}

Keterangan: Huruf yang sama pada satu kolom kejadian penyakit menunjukan hasil yang tidak berbeda nyata pada setiap perlakuannya berdasarkan Uji Duncan taraf nyata $5 \%$

Kemunculan penyakit juga sangat dipengaruhi oleh kondisi lingkungan. Pada perlakuan semprot bibit (SB) menunjukkan nilai pesentase kejadian penyakit di bawah perlakuan SD, SI, dan SS. Hal ini disebabkan adanya perbedaan kondisi suhu dan kelembapan pada perlakuan. Suhu inkubasi perlakuan SD, SI, dan SS berada pada suhu ruang $\left(22{ }^{\circ} \mathrm{C}-25^{\circ} \mathrm{C}\right)$ dengan kelembapan $80 \%$ - 90\% sebelum dipindah tanam ke dalam rumah kaca. Sementara itu, pada perlakuan SB masa inkubasi mengikuti kondisi lingkungan di rumah kaca dengan suhu $22,22{ }^{\circ} \mathrm{C}-34,3^{\circ} \mathrm{C}$ dan kelembapan $54 \%$ $70 \%$. Perbedaan kondisi suhu dan kelembapan akan sangat memengaruhi proses infeksi penyakit bulai.

Bonde et al. (1992) menyatakan bahwa infeksi sistemik $P$. maydis akan terjadi pada kisaran suhu $8^{\circ} \mathrm{C}-36^{\circ} \mathrm{C}$, namun semakin tinggi suhu menyebabkan penurunan kemampuan infeksi pada tanaman. Selain itu, kelembapan yang mendukung infeksi dan munculnya kejadian penyakit bulai berkisar $80 \%$ - 100\% (Rustiani et al., 2015a). Rendahnya kondisi kelembapan di rumah kaca turut memengaruhi ekspresi munculnya penyakit pada tanaman jagung.

\section{SIMPULAN}

Keberhasilan inokulasi buatan akan sangat dipengaruhi oleh interaksi antara tanaman inang, patogen, dan kondisi lingkungan. Teknik inokulasi buatan $P$. maydis dalam skala rumah kaca akan lebih efisien dan dapat dilakukan berulang menggunakan bahan tanam kecambah jagung dengan menggunakan metode sisip daun (SD).

\section{DAFTAR PUSTAKA}

Agrios, G. N. (2005). Plant Pathology (5 ${ }^{\text {th }}$ ed.). Pp: 79-80 Burlington USA: Elsevier Academic Press. 
Aqil, M., Rapar, C., \& Zubachtirodin. (2012). Deskripsi Varietas Unggul Jagung $\left(7^{\text {th }}\right.$ ed.). Halaman 17. Maros: Badan Penelitian dan Pengembangan Tanaman Pertanian Kementrian Pertanian.

Bock, C. H., Jeger, M. J., Mughogho, L. K., Cardwell, K. F., Mtisi, E., Kaula, G., \& Mukansabimana, D. (2000). Variability of Peronosclerospora sorghi isolates from different geographic locations and hosts in Africa. Mycological Research, 104(1), 61-68. https://doi.org/10.1017/\$0953756299 008965

Bonde, M. R. (1982). Epidemiology of downy mildew diseases of maize, sorghum and pearl millet. Tropical Pest Management, 28(1), 49-60. https://doi.org/10.1080/09670878209 370674

Bonde, M. R., Peterson, G. L., Kenneth, R. G., Vermeulen, H. D., Sumartini, \& Bustaman, M. (1992). Effect of temperature on conidial germination and systemic infection of maize by Peronosclerospora species. Ecology and Epidemiology, 82(1), 104-109. https://doi.org/10.1094/Phyto-82-104

Burhanuddin. (2011). Identifikasi cendawan penyebab penyakit bulai pada tanaman jagung di Jawa Timur dan Pulau Madura. Suara Perlindungan Tanaman, 1(1), 21-25.

CIMMYT. (2012). Downy mildew (extended information). Retrieved August 24, 2018, from http://maizedoctor.org/downymildew-extended-information

FAO. (2016). Save and grow in practice: maize, rice and wheat. A guide to sustainable. Rome: Food and Agriculture Organization. https://doi.org/10.1007/s13398-0140173-7.2

Giri, P., Taj, G., \& Kumar, A. (2013).
Comparison of artificial inoculation methods for studying pathogenesis of Alternaria brassicae (Berk.) Sacc on Brassica juncea (L.) Czern. (Indian mustard). African Journal of Biotechnology, 12(18), 2422-2426. https://doi.org/10.5897/AJB12.2803

Hikmawati, Kuswinanti, T., Melina, \& Pabendon, M. B. (2011). Karakterisasi morfologi Peronosclerospora spp., penyebab penyakit bulai pada tanaman jagung, dari beberapa daerah di Indonesia. Jurnal Fitomedika, 7(3), 159-161.

Korlina, E., \& Amir, A. M. (2015). Efektivitas jenis fungisida terhadap penyakit bulai (Peronosclerospora maydis) pada jagung. In Prosiding Seminar Nasional Serealia, "Peningkatan Peran Penelitian dan Pengembangan Serealia dalam Mendukung Swasembada Pangan" (pp. 443-448). Maros 30 April 2015.

Muis, A., Nonci, N., \& Pabendon, M. B. (2016). Geographical distribution of Peronosclerospora spp., the causal organism of maize downy mildew, in Indonesia. AAB Bioflux, 8(3), 143-155.

Narayana, Y. D., Mughogho, L. K., \& Bandyopadhyay, R. (1995). Evaluation of greenhouse inoculation techniques to screen sorghum for resistance to downy mildew. Euphytica, 86(1), 4953. https://doi.org/10.1007 /BF00035938

Pakki, S. (2017). Kelestarian ketahanan varietas unggul jagung terhadap penyakit bulai Peronosclerospora maydis. Penelitian Pertanian Tanaman Pangan, 1(1), 37-44. https://doi.org/10.21082/jpptp.v1n1.2 017.p37-44

Perera, K. T. G. K., \& Weerasinghe, T. K. (2014). A study on the impacts of corn cultivation (Zea mays (L.) Family Poaceae) on the properties of soil. International Journal of Scientific and 
Research Publications, 4(7), 1-6.

Radwan, G. L., Perumal, R., Isakeit, T., Magill, C., Prom, L. K., \& Little, C. R. (2011). Screening exotic sorghum germplasm, hybrids, and elite lines for resistance to a new virulent pathotype (P6) of Peronosclerospora sorghi causing downy mildew. Plant Healt Progress, 1(1), 1-16. https://doi.org/10.1094/PHP-20110323-01-RS.Abstract

Runge, F., Ndambi, B., \& Thines, M. (2012). Which morphological characteristics are most influenced by the host matrix in downy mildews? a case study in Pseudoperonospora cubensis. PLOS ONE, 7(11). https://doi.org/10.1371 /journal.pone.0044863

Rustiani, U. S. (2015). Keragaman dan Pemetaan Penyebab Penyakit Bulai Jagung di 13 Provinsi Indonesia. Repository Intitut Pertanian Bogor. Institut Pertanian Bogor, Bogor.

Rustiani, U. S., Sinaga, M. S., Hidayat, H., \& Wiyono, S. (2015a). Ecological characteristic of Peronosclerospora maydis in Java, Indonesia. International Journal of Science, 19(1), 159-167.

Rustiani, U. S., Sinaga, M. S., Hidayat, S. H., \& Wiyono, S. (2015b). Tiga spesies Peronosclerospora penyebab penyakit bulai jagung di Indonesia. Berita Biologi, 14(1), 29-37.

Surtikanti. (2013). Cendawan Peronosclerospora sp. penyebab penyakit bulai di Jawa Timur. Inovasi Teknologi Pertanian, 1, 57-67.

Talanca, A. H. (2013). Status penyakit bulai pada tanaman jagung dan pengendaliannya. In Seminar Nasional Inovasi Teknologi Pertanian "Peranan dan Aplikasi Teknologi Pertanian Mendukung Ketahanan Pangan Nasional" (Vol. 1, pp. 76-87). Banjarbaru, 26-27 Maret 2013.
Telle, S., Shivas, R. G., Ryley, M. J., \& Thines, M. (2011). Molecular phylogenetic analysis of Peronosclerospora (Oomycetes) reveals cryptic species and genetically distinct species parasitic to maize. European Journal of Plant Pathology, 130(4), 521-528. https://doi.org/10.1007/s10658-0119772-8

Widiantini, F., Pitaloka, D. J., Nasahi, C., \& Yulia, E. (2017). Perkecambahan Peronosclerospora spp. asal beberapa daerah di Jawa Barat pada fungisida berbahan aktiff metalaksil, dimetomorf, dan fenamidon. Jurnal Agrikultura, 28(2), 95-102.

Widiantini, F., Yulia, E., \& Purnama, T. (2015). Morphological variation of Peronosclerospora maydis, the causal agent of maize downy mildew from different locations in Java-Indonesia. Journal of Agricultural Engineering and Biotechnology, 3(2), 23-27. https://doi.org/10.18005/JAEB030200 2

Yao, C., Magill, C. W., Frederiksen, R. A., Bonde, M. R., Wang, Y., \& Wu, P. (1991). Detection and identification of $P$. sacchari in maize by DNA hybridiazation. Phytopathology, 81, 901-905.https://doi.org/10.1094 /Phyto-81-901 